
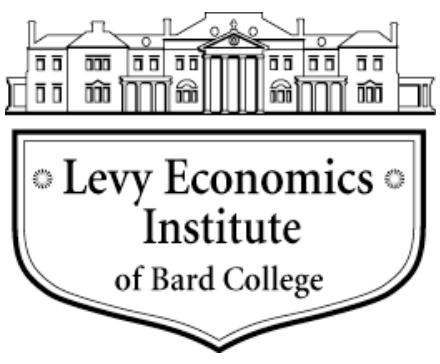

Working Paper No. 815

\title{
Public Preferences for Redistributive Policies in Israel
}

\author{
by \\ Yuval Elmelech \\ Levy Economics Institute of Bard College
}

September 2014 * I thank Sanjaya DeSilva, Gidon Eshel, Tamar Khitarishvili, Kijong Kim, and Joel Perlmann for helpful
comments on previous versions of this paper.

The Levy Economics Institute Working Paper Collection presents research in progress by Levy Institute scholars and conference participants. The purpose of the series is to disseminate ideas to and elicit comments from academics and professionals.

Levy Economics Institute of Bard College, founded in 1986, is a nonprofit, nonpartisan, independently funded research organization devoted to public service. Through scholarship and economic research it generates viable, effective public policy responses to important economic problems that profoundly affect the quality of life in the United States and abroad.

Levy Economics Institute

P.O. Box 5000

Annandale-on-Hudson, NY 12504-5000

http://www.levyinstitute.org

Copyright (C) Levy Economics Institute 2014 All rights reserved

ISSN 1547-366X 


\begin{abstract}
This paper contributes to the literature on inequality and welfare policy by studying public support for redistributive policies in Israel, a society with an extreme level of socioeconomic inequality. Drawing on the relevant literature and taking into consideration the distinct demographic makeup of contemporary Israeli society, the study aims to describe public support for opportunity-enhancing and outcome-based redistributive policies and to explore the extent to which individual economic and demographic characteristics are associated with policy preferences. Analysis of data from a unique topical module of the 2008 Israel Social Survey reveals that support for opportunity-based programs is strong overall, but that the Israeli public is deeply divided along ethnic lines, religious affiliation, and immigration status. While results from multinomial regression analyses provide support for the self-interest theory, the findings also underscore the significance of various demographic and social indicators as determinants of policy preferences. These findings are discussed in light of the current debates on the sources of, and possible remedies for, the growing social and economic polarization within Israeli society.
\end{abstract}

Keywords: Israel; Public Opinion; Redistributive Policies; Social Policy Preferences

JEL Classifications: D63, H59 


\section{INTRODUCTION}

There is a general consensus among social scientists that extreme economic disparities have detrimental social and political consequences. Studies report that a high level of inequality is associated with health disparities (Miech et al. 2011), it tends to hinder economic growth (Persson and Tabellini 1994), deepens social divisions, and is associated with inequality in political power and participation (Busemeyer et al. 2009; Neckerman and Torche 2007). While research on socioeconomic inequality is quite extensive, we know less about people's views on inequality and their support for specific measures to reduce it. Studying people's views about redistributive measures, particularly the provision of welfare to low income families, is important for several reasons. First, these preferences reflect public belief in societal values such as social justice, and equal opportunities and form expectations from policy makers. Second, public support for specific redistributive policies reflect self-interest of various economic classes and demographic groups while resistance among certain groups to some policies - such as affirmative action, and welfare programs - signifies potential antagonism along economic and demographic lines (Kluegel and Smith 1983). Lastly, people's opinions and preferences have substantial influence on policies, particularly when the topic is perceived as crucial to the public (Burstein 1998; Brooks and Manza 2006).

Israel is an interesting case study for analysis of public support for welfare programs and other redistributive policies. In comparison to other industrial societies, socioeconomic inequality and poverty rates in Israel are high, and there is growing public frustration with the historically high level of inequality the country is experiencing. In recent years, this discontent has led to sporadic eruptions of protests over what is viewed by many Israelis as extreme concentration of wealth, and preferential treatment for certain sectors of the population. While these protests received much media attention, we know very little about the public's views regarding particular measures to reduce inequality. The diverse demographic makeup of Israeli society and the visible correlation between demographic characteristics and economic status suggests strong polarization in policy preferences along ethnic and national origin, immigration status, age, and religiosity. With few exceptions (Lewin-Epstein et al. 2003; Cohen, Mizrahi and Yuval 2011; Shalev 2007) research on public support for more egalitarian redistribution of resources in Israel has been scarce and little is known about support for particular redistributive 
policies, and the extent to which policy preferences vary by demographic and socioeconomic background.

The objectives of this study are threefold: First, to describe public support for redistributive policies in Israel. Instead of either measuring general public support for redistribution policies, or focusing on one specific policy (e.g., welfare policy expansion), , this paper studies public support for four particular opportunity-enhancing and outcome-based policies: investment in education, creation of more jobs, assistance to low income families, and tax increase on the rich. Second, drawing on relevant literature on public support for redistributive policies, the paper explores the extent to which individual economic and demographic attributes are associated with policy preferences. Third, special attention will be given to the role of social capital and attachment to larger social networks in shaping support for particular social policies. The study also assesses the extent to which these, actual or potential, social resources are mediating the association between demographic characteristics and policy preferences.

The paper is divided into five sections. The first section outlines the literature on public support for redistributive policies while focusing on those determinants that are relevant to the Israeli case. The next section covers key economic and demographic patterns of contemporary Israeli society, and the third describes the data and methodology. The fourth reports the key descriptive findings, as well as results from a multinomial regression analysis, and the last section summarizes the key findings and conclusions.

\section{Theoretical Considerations: Demographic and Social Determinants of Policy Preferences}

Redistributive policies can be divided into two general categories- “opportunity-enhancing" and "outcome-based" policies (Shelton and Wilson 2009). Opportunity-enhancing policies aim to reduce inequalities and improve the life chances of disadvantaged groups through programs that enhance equal opportunities, mainly in education and in the labor market. These programs emphasize individual merit as the determining factor for upward mobility and the equal distribution of socioeconomic resources in society. Outcome-based policies aim to equalize outcomes and tend to focus on specific demographic and economic groups (e.g., the poor, women, ethnic minorities) rather than on individual qualifications (e.g., academic credentials, work experience, and test scores) (Shelton and Wilson 2009). 
Research on public views about government measures to reduce inequality in developed countries typically reports strong support for opportunity-enhancing measures as well as substantial variation in policy preferences along economic and demographic lines. According to the self-interest theory (Bobo and Klueger 1993), people's policy preferences are contingent on the degree to which proposed policies are viewed as beneficial or detrimental to the groups with which they associate themselves (Oh et al. 2010). Individuals who are vulnerable economically - the poor, the young, women — and likely to benefit from public assistance programs, are consistently more supportive of these programs (Hasenfeld and Rafferty 1989; Svallfors, 1997; Edlund, 1999; Blekesaune and Quadagno 2003; Blekesaune 2007; McCall and Kenworthy 2009), while those who are more secure economically are less supportive of welfare expansion and more likely to endorse policies that benefit the rich, such as lowering the tax rate (Edlund 1999). However, a number of studies also revealed the limitation of the self-interest theory; indeed, when the focus of the analysis shifts from sheer economic measures to social and demographic attributes — such as education, age, ethnicity and social capital — the capability of the self-interest theory to explain policy preferences is more limited, and other explanations are proposed for the findings.

Research on educational attainment and views about redistributive policies reports results ranging from negative or no association between level of education and support for social welfare expansion (Jackman \& Muha 1984) to positive correlation between education and approval of welfare programs. The stronger support for welfare provision among the highly educated is typically attributed to the "enlightenment" principle - that is, the supposed contribution of formal education to the development of democratic values, which evoke greater commitment to equality and civic responsibility (McClosky and Brill 1983; Sullivan et al.1982 in Hasenfeld and Rafferty 1989).

The aging of the population in many industrial societies has drawn attention to generational variation in policy preferences. Support for self-interest theory is provided by research indicating that younger people, who are economically more vulnerable, usually express stronger support for increased government investment in education and welfare programs than older age groups (Busemeyer et al. 2009). There is also support for a different age pattern. Rather than competition over limited resources, a growing number of studies report strong intergenerational ties between the old and the young, and document sound support among the elderly 
for policies that benefit younger age groups, such as government spending on education (Street and Cossman 2006).

Studying the association between racial/ethnic origin and policy preferences has also revealed interesting results. Studies in the US report that racial and ethnic minorities are more likely than whites to favor redistributive policies, even after socioeconomic characteristics, such as education and labor market attainment, are taken into account (Bobo 1991; Gilliam and Whitby 1989). The remaining gaps are typically explained by the distinct social, not solely economic, experiences of minority group members. The social ties that middle class minorities maintain with low-income members of the same racial/ethnic group seem to perpetuate the notion of perceived group threat and result in strong support among minorities for outcomebased policies (Wilson 2001: 102). Indeed, in recent years, growing attention has been given to social networks and informal support system as factors that shape people's views about redistributive policies.

While research on the topic is relatively scarce, evidence suggests that in multi-ethnic immigrant societies, policy preferences and support for redistributive policies vary by level of social integration. Studies on Latinos in the US, for example, found that acculturation is negatively correlated with support for welfare; as immigrants assimilate into the mainstream society their general trust in the government tends to decrease (Michelson 2003). Consequently, the confidence of these assimilated immigrants and their offspring in the government ability to provide services to families in need diminishes with time, and the overall support they express for increased government spending on welfare declines considerably (Branton 2007: 298). These findings remain statistically significant even after socioeconomic characteristics are controlled for. Another line of research suggests a direct link between social networks and policy preferences. Social capital in the form of interactions with friends and relatives is often associated with improvement in subjective and objective indicators of well-being, and it involves financial benefits in the form of intergenerational transfers of material resources. These transfers alleviate economic hardship, decrease the sense of vulnerability, and reduce dependency on welfare (Warren et al. 2001)." Religiosity is another factor that is often used as a proxy for community integration and reliance on informal support networks. Using the European Social Survey of 2002-2006, Stegmueller et al. (2012) report that individuals who define themselves as religious are more likely than secular people to oppose income redistribution through the state. The author attributes this finding to the greater reliance among 
religious respondents on religious communities and organizations as a source of material support (see also Svallfors 2007).

Three patterns emerged from the review of the literature. First, people's support for redistributive policies varies substantially by their economic and socio-demographic background. Second, some of the observed association between demographic characteristics (e.g., age, ethnic origin) and policy preferences is explained by the correlation between one's demographic background and her/his economic status. Third, actual or potential resources one has access to through social networks emerge as important, though often neglected, determinants of policy preferences.

\section{The Israeli Setting}

Israeli society is an interesting, yet unexplored, setting for the study of public views about redistributive policies. While Israelis typically express strong support for state intervention in the provision of welfare services to the poor, they also value government spending on public education, health, jobs creation and infrastructure as a means to reduce socioeconomic gaps (Shalev 2007). However, in the past three decades, Israel has moved from a model of social welfare towards a conservative model of welfare protection (Zilberfarb 2005) that leaves the more vulnerable segments of the population dependent on private resources and market forces. These transformations have coincided with growing economic inequality and high rates of poverty (OECD 2013). In 2008, nearly half (48.3\%) of the income whose sources were derived from the labor market and capital gains was in the hands of the top quintile, while only $3 \%$ was held in the hands of the bottom quintile (National Insurance Institute 2009: 25).

These extreme socioeconomic disparities are strongly correlated with demographic and social characteristics. Indeed, one of the explanations for the high level of inequality in Israel is the persistent economic divide between the Jewish majority and the (non-Jewish), mainly Arab, minority which is spatially segregated, and socially and economically marginalized. The Arab population in Israel is composed mainly of Muslims (84.3\%), but also Druze (8.0\%) and Christians (7.7\%) (Israel Central Bureau of Statistics 2013). The socioeconomic status of the Arab citizens has been attributed to an array of social and structural factors. These include limited parental resources, traditional gender roles and higher fertility rates, as well as regional residential concentration, labor market segmentation, poor quality of public schools, limited 
access to welfare assistance, and labor market discrimination that has historically limited opportunities for upward mobility (Ghanem 2001; Sa'di 1995; Semyonov and Cohen 1990; AlHaj 1995; Lewin-Epstein and Semyonov, 1994; Cohen and Haberfeld 1998; Okun and Friedlander 2005). While both Arabs and Jews benefit from policy measures to reduce poverty, the contribution of these policies to poverty reduction is larger for Jewish families (Endeweld et al 2008: 13).

The Jewish population is ethnically divided between Jews of Asian-African origin (Mizrahim) and Jews of European-American origin (Ashkenazim). In general, Ashkenazi immigrants arrived earlier, and came with higher human capital. The socioeconomic assimilation of most Ashkenazi immigrants, who typically arrived before, or immediately after, the establishment of the state in 1948, was successful. On the other hand, a relatively large number of Mizrahi immigrants, arrived in the 1950s and early 1960s, resided in the peripheral regions of the country, faced more limited opportunities for economic mobility and lagged behind the Ashkenazi in measures such as education, occupational status, income and wealth. Contrary to its melting pot ideology, the Mizrahi-Ashkenazi gaps in education and economic status remain substantial in the second- and third-generation (Cohen et al. 2007; Cohen and Haberfeld 1998; Perlmann and Elmelech 2010; But see Friedlander et al. 2002).

Immigration continues to play a key role in the demographic makeup of the Israeli society. Indeed, Jewish immigration and fertility, two key demographic factors behind population growth, have been extensively supported by Israeli governments. The Jewish population has increased drastically since the late 1980s as a result of the influx of almost one million immigrants from the former Soviet Union, of whom the vast majority arrived during the 1990s. While their status as recent immigrants hinder their economic assimilation and acculturation into mainstream Israeli society, members of this group have benefited from generous government support in the form of housing subsidies and vocational training. Israel's high fertility rate - about 3 children per woman, compared with an average rate of 1.7 in OECD countries (Central Bureau of Statistics 2013) - is attributed not only to the strong cultural and religious support for fertility, and to nationalist sentiments, but also to unprecedented pro-natal policies; the state provides financial incentives in the form of generous child-allowance programs, and the provision of virtually universal funding for fertility treatments for all women regardless of marital status, and ethnic or religious origin (Birenbaum-Carmeli 2009; Manski and Mayshar 2002; Anson and Meir 1996). 
The provision of financial assistance to families with a high number of children is one of the substantial means of welfare transfers benefiting two groups who tend to have high fertility rates - Arab citizens, and religious Jews. While Israel was established as a Jewish state, most Jews in Israel do not define themselves as religious, and one of the most severe sociocultural and political conflicts within Israeli society today is that between religious and non-religious Jews (Levy et al. 2004; Waxman 2004). The increasing social rift and residential segregation between secular and religious Jews, and the substantial dependence on welfare of ultra-orthodox Jews, a group with high unemployment and fertility rates - during a period of welfare state retrenchment has led to wide discontent among the secular population (Waxman 2004).

Welfare state retrenchment and the overall high cost of living, which led to mass public protests in 2011, accentuated the role of the Israeli family as a key provider of financial and social support to its members. Research in Israel has shown very strong familial and generational ties and a broad cultural acceptance of parental responsibility to assist adult children. Reliance of young adults on parental resources for major expenses such as housing and schooling is partially attributed to cultural emphasis on familism, the high cost of living, and the erosion of public welfare provisions which amplify the need to rely on family resources (Spilerman and Elmelech 2003; Spilerman 2004).

\section{DATA AND VARIABLES}

The data come from the 2008 Israel Social Survey Public Use File (PUF) acquired from the Israel Social Sciences Data Center (ISDC). The Israel Social Survey has been carried out annually since 2002 on a representative sample of persons aged 20 and older. The survey integrates data on objective measures of well-being, such as education, health, employment and income, typically collected in various surveys conducted by the Israeli Central Bureau of Statistics (CBS), as well as beliefs and attitudes regarding these facts. The information is collected through face-to-face interviews by CBS interviewers conducted in Hebrew, Arabic and Russian that last for about an hour. Each year, the social survey questionnaire includes a unique variable module that focuses on a specific policy-relevant topic; the 2008 module investigated social mobility and included valuable information on socioeconomic status and attitudes regarding redistributive policies. The sample includes 7,237 respondents. 
The dependent variable is the answer to the question, "In your opinion, what action should the State take in order to reduce the gaps in society?" Four response categories are "Invest in education," "Encourage employment and creation of new workplaces," "Increase allowances and support to the lower-income populations" and "Raise taxes among the higherincome populations." While in practice these policy options are not necessarily mutually exclusive - for example, money raised from taxes could be used to finance education or job creation-respondents were asked to choose only one category. Having four categories that represent both opportunity-enhancing and outcome-based policies, allow us to broaden the discussion and move beyond the limited study of public support for welfare. Based upon the literature cited above, three sets of explanatory variables are included in the analysis (see Appendix A for a complete list of the variables). The unit of analysis is the individual, but information on the household is also available and will be included in the models as control variables.

Three sets of independent variables are included. The socioeconomic variables include educational attainment, annual salary, and work status (self-employed) of the respondent. Two additional measures of economic status are number of earners in the household and homeownership, which is a key indicator of household wealth in Israel (Lewin Epstein et al. 1997). The Demographic variables include ethnic origin, nationality, immigration status, gender, and age. Additional demographic indicators included as control variables are marital status, number of children, self-reported health status, household size, and district of residence. These variables have been associated with economic vulnerability (i.e., caring for a relatively large number of children, being a widow, or reporting poor health), and policy preferences (Busemeyer et al. 2009). Drawing on recent literature on social capital and policy preferences, the key relevant social characteristics available in the data are religiosity, frequency of social interactions with friends, whether the respondent states that she/he has people to rely on, and the respondent's level of Hebrew proficiency. 


\section{FINDINGS: DESCRIPTIVE STATISTICS}

Table 1 provides a description of the key explanatory factors for the general research population (Column 1) and for each of the four categories of the dependent variable (Columns 2-5). Of the total number of respondents, ${ }^{2}$ the majority believes that opportunity-enhancing policies are the preferred remedy for inequality, a pattern that reflects the general support for merit as a mechanism of redistribution of resources (Lewin Epstein et al. 2003); 41.5\% of the population chose investment in education and 34.8\% chose creation of new jobs. Less than 5\% selected the increase in taxes among the higher-income populations and about a fifth of the respondents (19.3\%) believe that the government should "increase allowances and support the lower income population."

Table 1 Comparison of Key Explanatory Variables by Redistributive Policy Categories (Weighted)

\begin{tabular}{|c|c|c|c|c|c|}
\hline & $\begin{array}{c}\text { Total } \\
\text { Population }\end{array}$ & $\begin{array}{c}\text { Category 1 } \\
\text { Invest in } \\
\text { Education }\end{array}$ & $\begin{array}{c}\text { Category 2 } \\
\text { Increase } \\
\text { Support to } \\
\text { Low-income } \\
\text { Populations }\end{array}$ & $\begin{array}{c}\text { Category 3 } \\
\text { Create } \\
\text { New Jobs }\end{array}$ & $\begin{array}{c}\text { Category 4 } \\
\text { Raise } \\
\text { Taxes on } \\
\text { the Rich }\end{array}$ \\
\hline Ethnicity & & & & & \\
\hline Immigrant-Europe (Askenazi) & .079 & .111 & .042 & .061 & .091 \\
\hline & $(.270)$ & $(.314)$ & $(.200)$ & $(.239)$ & $(.278)$ \\
\hline Israel-Ashkenazi & .079 & .112 & .045 & .061 & .065 \\
\hline & $(.270)$ & $(.316)$ & $(.207)$ & $(.239)$ & $(.246)$ \\
\hline Israel-Mizrahi (As/Af) Parents & .136 & .155 & .134 & .110 & .167 \\
\hline & $(.343)$ & $(.362)$ & $(.341)$ & $(.313)$ & $(.372)$ \\
\hline Immigrant-Mizrahi (As/Af) & .105 & 104 & .137 & .083 & .148 \\
\hline & $(.307)$ & $(.306)$ & $(.344)$ & $(.277)$ & $(.355)$ \\
\hline Israel-Mix & .261 & .321 & .244 & .209 & .188 \\
\hline & $(.439)$ & $(.466)$ & $(.429)$ & $(.409)$ & $(.390)$ \\
\hline Immigrant-FSU & .175 & .137 & .190 & .202 & .260 \\
\hline & $(.380)$ & $(.344)$ & $(.392)$ & $(.402)$ & $(.438)$ \\
\hline Arab-Muslim & .130 & .038 & .175 & .225 & .061 \\
\hline & $(.337)$ & $(.192)$ & $(.380)$ & $(.417)$ & $(.239)$ \\
\hline & & & & & \\
\hline
\end{tabular}

\footnotetext{
${ }^{2}$ Of the 7,237 cases, 137 (1.9\%) were excluded because the respondents did not select one of the four categories of the dependent variable. Some independent variables included small number of responses that were coded as "Unknown" (for example, 3 "unknown" cases in the variable Education, 26 "unknown" cases in the variable religiosity, 9 unknown cases in Homeownership, 18 'Unknown”' in Frequency of meeting Friends, 70 'unknown' in "people to count on"); these responses were incorporated into one of the other categories. When the number of 'Unknown' values was relatively high, as in the variable 'salary,' the category 'unknown' was included in the models as a control variable and the coefficient was not statistically significant.
} 


\begin{tabular}{|c|c|c|c|c|c|}
\hline Arab-Other (Christian and & .029 & .016 & .029 & .046 & .019 \\
\hline & $(.168)$ & $(.127)$ & $(.168)$ & $(.209)$ & $(.137)$ \\
\hline \multicolumn{6}{|l|}{ Religiosity } \\
\hline \multirow[t]{2}{*}{ Very Religious/Religious } & .229 & .168 & .350 & .247 & .138 \\
\hline & $(.420)$ & $(.373)$ & $(.477)$ & $(.431)$ & $(.345)$ \\
\hline \multirow[t]{2}{*}{ Not So Religious } & .376 & .351 & .378 & .398 & .428 \\
\hline & $(.484)$ & $(.477)$ & $(.485)$ & $(.389)$ & $(.494)$ \\
\hline \multirow[t]{2}{*}{ Not Religious } & .368 & .452 & .255 & .327 & .389 \\
\hline & $(.482)$ & $(.497)$ & $(.436)$ & $(.469)$ & $(.487)$ \\
\hline \multicolumn{6}{|l|}{ Language Proficiency } \\
\hline \multirow[t]{2}{*}{ Very good } & .622 & .748 & .499 & .548 & .567 \\
\hline & $(.484)$ & $(.434)$ & $(.500)$ & $(.497)$ & $(.495)$ \\
\hline \multirow[t]{2}{*}{ Good } & .281 & .218 & .330 & .327 & .300 \\
\hline & $(.449)$ & $(.412)$ & $(.470)$ & $(.469)$ & $(.458)$ \\
\hline \multirow[t]{2}{*}{ Poor } & .095 & .033 & .170 & .124 & .131 \\
\hline & $(.294)$ & $(.180)$ & $(.375)$ & $(.329)$ & $(.337)$ \\
\hline \multicolumn{6}{|l|}{ Meet Friends } \\
\hline \multirow[t]{2}{*}{ No } & .116 & .073 & .216 & .101 & .161 \\
\hline & $(.320)$ & $(.261)$ & $(.412)$ & $(.306)$ & $(.367)$ \\
\hline \multirow[t]{2}{*}{ 1-2 a Month or Less } & .121 & .120 & .123 & .122 & .112 \\
\hline & $(.326)$ & $(.324)$ & $(.328)$ & $(.327)$ & $(.315)$ \\
\hline \multirow[t]{2}{*}{ 1-2 a Week } & .350 & .366 & .279 & .374 & .316 \\
\hline & $(.476)$ & $(.481)$ & $(.448)$ & $(.483)$ & $(.465)$ \\
\hline \multirow[t]{2}{*}{ Daily } & .412 & .440 & .381 & .398 & .409 \\
\hline & $(.492)$ & $(.496)$ & $(.485)$ & $(.489)$ & $(.491)$ \\
\hline \multirow[t]{2}{*}{ People to Count on (Yes) } & .890 & .927 & .833 & .885 & .836 \\
\hline & $(.312)$ & $(.259)$ & $(.372)$ & $(.318)$ & $(.370)$ \\
\hline \multirow[t]{2}{*}{ Health Status (1-4 High) } & 3.19 & 3.34 & 2.94 & 3.18 & 2.92 \\
\hline & $(.878)$ & $(.784)$ & $(1.03)$ & $(.832)$ & $(1.01)$ \\
\hline \multirow[t]{2}{*}{ Sex (Female) } & .515 & .466 & .581 & .536 & .507 \\
\hline & $(.499)$ & $(.498)$ & $(.493)$ & $(.498)$ & $(.499)$ \\
\hline \multirow[t]{2}{*}{ Household Size } & 3.69 & 3.51 & 3.84 & 3.87 & 3.26 \\
\hline & $(1.72)$ & $(1.59)$ & $(1.88)$ & $(1.75)$ & $(1.67)$ \\
\hline \multicolumn{6}{|l|}{ Age } \\
\hline \multirow[t]{2}{*}{ Less than 30} & .241 & 219 & .265 & .265 & .167 \\
\hline & $(.428)$ & $(.413)$ & $(.441)$ & $(.441)$ & $(.373)$ \\
\hline \multirow[t]{2}{*}{ 30-39 } & .221 & .226 & .203 & .228 & .200 \\
\hline & $(.415)$ & $(.418)$ & $(.402)$ & $(.419)$ & $(.400)$ \\
\hline \multirow[t]{2}{*}{$40-49$} & .169 & .183 & .145 & .172 & .149 \\
\hline & $(.375)$ & $(.385)$ & $(.352)$ & $(.377)$ & $(.356)$ \\
\hline $50-64$ & .222 & .237 & .186 & .218 & .264 \\
\hline
\end{tabular}




\begin{tabular}{|c|c|c|c|c|c|}
\hline & $(.415)$ & $(.425)$ & $(.389)$ & $(.412)$ & $(.441)$ \\
\hline \multirow[t]{2}{*}{$65+$} & .144 & .135 & .198 & .116 & .217 \\
\hline & $(.351)$ & $(.342)$ & $(.398)$ & $(.320)$ & $(.412)$ \\
\hline \multirow[t]{2}{*}{ Number of Children } & 2.23 & 2.09 & 2.61 & 2.19 & 2.11 \\
\hline & $(1.92)$ & $(1.72)$ & $(2.24)$ & $(1.94)$ & $(.179)$ \\
\hline \multicolumn{6}{|l|}{ Marital Status } \\
\hline \multirow{2}{*}{ Married } & .655 & .675 & .605 & .667 & .595 \\
\hline & $(.475)$ & $(.468)$ & $(.488)$ & $(.471)$ & $(.490)$ \\
\hline \multirow[t]{2}{*}{ Divorced/Separated } & .068 & .061 & .088 & .062 & .103 \\
\hline & $(.252)$ & $(.239)$ & $(.283)$ & $(.241)$ & $(.304)$ \\
\hline \multirow{2}{*}{ Widowed } & .055 & .040 & .091 & .046 & .111 \\
\hline & $(.229)$ & $(.196)$ & $(.288)$ & $(.211)$ & $(.314)$ \\
\hline \multirow[t]{2}{*}{ Single } & .219 & .223 & .214 & .222 & .189 \\
\hline & $(.414)$ & $(.416)$ & $(.410)$ & $(.416)$ & $(.391)$ \\
\hline \multirow[t]{2}{*}{ Number of Earners } & 1.53 & 1.62 & 1.27 & 1.56 & 1.45 \\
\hline & $(1.05)$ & $(.995)$ & $(1.10)$ & $(1.05)$ & $(1.137)$ \\
\hline \multicolumn{6}{|l|}{ Salary } \\
\hline \multirow[t]{2}{*}{ Unemployed/Not in Labor Force } & .400 & .316 & .564 & .402 & .455 \\
\hline & $(.489)$ & $(.465)$ & $(.495)$ & $(.490)$ & $(.498)$ \\
\hline \multirow[t]{2}{*}{ INS $0-4,000$} & .149 & .137 & .168 & .156 & .123 \\
\hline & $(.356)$ & $(.344)$ & $(.374)$ & $(.363)$ & $(.328)$ \\
\hline \multirow[t]{2}{*}{ INS 4,001-7,000 } & .197 & .179 & .176 & .228 & .219 \\
\hline & $(.398)$ & $(.383)$ & $(.380)$ & $(.420)$ & $(.413)$ \\
\hline \multirow[t]{2}{*}{ INS 7,001-More than 21,000 } & .204 & .301 & .059 & .174 & .158 \\
\hline & $(.403)$ & $(.458)$ & $(.236)$ & $(.379)$ & $(.365)$ \\
\hline \multirow[t]{2}{*}{ Unknown } & .048 & .065 & .032 & .037 & .043 \\
\hline & $(.214)$ & $(.247)$ & $(.176)$ & $(.189)$ & $(.204)$ \\
\hline \multirow[t]{2}{*}{ Self-employed, Employs Others } & .076 & .097 & .035 & .073 & .073 \\
\hline & $(.265)$ & $(.297)$ & $(.186)$ & $(.261)$ & $(.260)$ \\
\hline \multicolumn{6}{|l|}{ Education } \\
\hline \multirow[t]{2}{*}{ Less than HS Matriculation } & .371 & .262 & .574 & .381 & .435 \\
\hline & $(.483)$ & $(.440)$ & $(.494)$ & $(.485)$ & $(.495)$ \\
\hline \multirow[t]{2}{*}{ Matriculation- Less than BA } & .382 & .394 & .323 & .400 & .385 \\
\hline & $(.485)$ & $(.488)$ & $(.467)$ & $(.489)$ & $(.486)$ \\
\hline \multirow[t]{2}{*}{ BA or Higher } & .245 & .342 & .101 & .218 & .179 \\
\hline & $(.430)$ & $(.474)$ & $(.302)$ & $(.413)$ & $(.383)$ \\
\hline \multirow[t]{2}{*}{ Homeowner (Yes) } & .711 & .722 & .667 & .725 & .678 \\
\hline & $(.453)$ & $(.447)$ & $(.471)$ & $(.446)$ & $(.466)$ \\
\hline \multicolumn{6}{|l|}{ District } \\
\hline \multirow[t]{2}{*}{ Jerusalem } & .107 & .084 & .123 & .128 & .077 \\
\hline & $(.309)$ & $(.278)$ & $(.329)$ & $(.334)$ & $(.267)$ \\
\hline \multirow[t]{2}{*}{ Northern } & .160 & .111 & .158 & .219 & .164 \\
\hline & $(.367)$ & $(.315)$ & $(.365)$ & $(.413)$ & $(.370)$ \\
\hline
\end{tabular}




\begin{tabular}{|r|c|c|c|c|c|}
\hline Haifa & .128 & .115 & .144 & .137 & .122 \\
\hline & $(.335)$ & $(.319)$ & $(.351)$ & $(.343)$ & $(.327)$ \\
\hline Central & .247 & .313 & .190 & .202 & .246 \\
\hline & $(.431)$ & $(.463)$ & $(.392)$ & $. .401)$ & $(.430)$ \\
\hline Tel Aviv & .192 & .231 & .199 & .139 & .201 \\
\hline Southern & $(.394)$ & $(.422)$ & $(.399)$ & $. .346)$ & $(.401)$ \\
\hline & $(.339)$ & $(.307)$ & $(.362)$ & $. .354)$ & $(.382)$ \\
\hline West Bank & .029 & .036 & .027 & .025 & .009 \\
\hline & $(.170)$ & $(.188)$ & $(.163)$ & $(.157)$ & $(.096)$ \\
\hline Number of Cases & & & & & \\
\hline & 7,190 & 3,003 & 1,373 & 2,498 & 316 \\
\hline
\end{tabular}

Note: Numbers represent percentages (standard deviations in parentheses).

A comparison of the values in the total population and those in each of the four categories provides a general picture of the association between policy preferences and the socioeconomic, demographic and social variables. Four findings merit attention: First, a relatively large proportion of the more vulnerable segments of the Israeli population seem to favor outcome-based policies, particularly welfare provision to low-income families. In comparison to other policy categories, Israelis who chose this category are more likely to have lower level of education, income, and homeownership rates, and to report poor health status. Those who selected this option also include a relatively high proportion of Mizrahi immigrants and women, and are more likely to be divorced/separated or widowed, have more children, report poor language proficiency, and define themselves as 'very religious' and less likely to meet friends. While the number of Israelis who chose the category "Raise taxes among rich" as their top policy choice is small (4.4\%), among some groups, this policy choice is more prevalent. Of those selecting this option, the proportion of Mizrahi Jews, older people (over 50), immigrants from the Former Soviet Union, widowed or divorced/separated, and those reporting poor health status, is large relative to the proportion of these groups in the population.

Second, while the two opportunity-enhancing policies were supported by the majority of the population, a breakdown of each of the two opportunity-enhancing categories by demographic and socioeconomic characteristics reveals distinct patterns. The relative size of the better-off respondents who support "Investment in education" as the preferred policy is high. Relative to their proportion in the general population, first and second generation Ashkenazi, and second generation Israelis of Israeli and mixed ethnic origin, are overrepresented in the 
category. This category is also associated with a high level of education, income, language proficiency and number of earners, as well as with being married, owning a home, being selfemployed, and with meeting friends and having people to count on in times of need. Those who selected "job creation" include a relatively large proportion of Muslims (22.5\%), a finding that likely reflects the higher unemployment rate and limited labor market opportunities in the segregated communities and peripheral regions where most Israeli Arabs live. This policy choice is also supported by other vulnerable populations, including a relatively large number of young Israelis, respondents living in large households, and women.

Third, while there are clear differences in demographic and socioeconomic attributes between respondents who support opportunity-enhancing policies and those who support outcome-based policies, in some cases, a relatively high proportion of members of a particular socioeconomic or demographic category express equally strong support for two distinct policy categories. For example, both the opportunity-enhancing category "Creation of new jobs" and the outcome-based category "support to low income populations" are common among Muslims, women, the young (20-29), and those defined themselves as "not so religious." Also, the categories "Creation of new jobs" and "raising taxes among high income populations" are popular among FSU immigrants and Israelis in the middle brackets of the income distribution.

Finally, Table 1 reveals that within each of the four policy categories, there is correlation between various explanatory variables, such as income and religiosity, education and ethnicity, immigration and language proficiency, and age and national origin. These findings, and particularly the clear association between economic status and some of the key social and demographic variables, raise theoretically important questions: Are the social and demographic variation in policy preferences a mere reflection of economic differences? To what extent do social and demographic characteristics have a direct impact (net of economic status) on people's support for specific redistributive policies? In order to answer these questions and investigate the relationship between these three sets of explanatory variables (demographic, socioeconomic and social) they were subjected to multivariate (multinomial) analysis. 


\section{FINDINGS: MULTIVARIATE ANALYSIS}

Table 2 presents results from multinomial regression analysis. Drawing on the above literature review, the main goal of this analysis is to explore the relationships between the various explanatory variables, and decipher the net effect that each set of factors - demographic, socioeconomic and social - has on views about redistributive policies. As mentioned above, the dependent variable "Views about Redistributive Policies" has four categories. The category "Increase allowances and support low income populations" was selected as the base (reference) category. Not only this category best reflects the focus of previous studies on public support for redistributive policies, but unlike a dichotomous dependent variable, the current analysis enables us to contrast support for welfare provision with three alternative options. For the sake of clarity, the table is divided into three sections which represent the three other categories of the dependent variable - "Invest in Education" (section A), "Raise taxes among the higher income populations" (section B) and "Encourage Employment and create new workplaces" (section C).

Table 2 Multinomial Regression of Policy Preferences (Standard Errors in Parentheses): Coefficients and Exponential Terms

\begin{tabular}{|c|c|c|c|c|c|c|}
\hline & \multicolumn{2}{|c|}{ (A) Education } & \multicolumn{2}{|c|}{ (B) Taxes } & \multicolumn{2}{|c|}{ (C) Job Creation } \\
\hline & B & Exp. & $\mathbf{B}$ & Exp. & $\mathbf{B}$ & Exp. \\
\hline \multirow[t]{2}{*}{ Number of Children } & -.021 & .97 & -.088 & .91 & $-.072 *$ & .93 \\
\hline & $(.031)$ & & $(.055)$ & & $(.029)$ & \\
\hline \multirow{2}{*}{ Health $(1 \mathrm{~L}-4 \mathrm{H})$} & $.253 * * *$ & 1.28 & -.036 & .96 & $.156^{* *}$ & 1.16 \\
\hline & $(.052)$ & & $(.088)$ & & $(.050)$ & \\
\hline \multirow[t]{2}{*}{ Number of Earners } & $.127 *$ & 1.13 & $.267 *$ & 1.30 & $.137 * *$ & 1.14 \\
\hline & $(.052)$ & & $(.095$ & & $(.049)$ & \\
\hline \multirow[t]{2}{*}{ Household Size } & $-.104 * *$ & .90 & $-.157 *$ & .85 & $-.072 *$ & .93 \\
\hline & $(.033)$ & & $(.062)$ & & $(.031)$ & \\
\hline \multicolumn{7}{|l|}{$\begin{array}{l}\text { Ethnicity (Omitted: Ashkenazi } \\
\text { Immigrant) }\end{array}$} \\
\hline \multirow[t]{2}{*}{ Israel - Ashkenazi origin } & $-.486 *$ & .61 & -.422 & .65 & -.319 & .72 \\
\hline & $(.211)$ & & $(.344)$ & & $(.222)$ & \\
\hline \multirow[t]{2}{*}{ Israel - Israeli /mixed origin } & $-.728 * * *$ & .48 & $-.765^{*}$ & .47 & $-.624 * * *$ & .53 \\
\hline & $(.176)$ & & $(.295)$ & & $(.184)$ & \\
\hline \multirow[t]{2}{*}{ Israel - Mizrahi origin } & $-.725 * * *$ & .48 & -.540 & .58 & $-.652 * * *$ & .52 \\
\hline & $(.184)$ & & $(.300)$ & & $(.192)$ & \\
\hline \multirow[t]{2}{*}{ Immigrant - Mizrahi origin } & $-.665 * * *$ & .51 & -.429 & .65 & $-.489 * *$ & .61 \\
\hline & $(.180)$ & & $(.285)$ & & $(.189)$ & \\
\hline \multirow[t]{2}{*}{ Immigrant - Former SU } & $-1.045 * * *$ & .35 & -.510 & .60 & -.319 & .72 \\
\hline & $(.180)$ & & $(.283)$ & & $(.183)$ & \\
\hline \multirow[t]{2}{*}{ Arab-Muslim } & $-1.128 * * *$ & .32 & $-.782 *$ & .45 & $.626 * *$ & 1.87 \\
\hline & $(.215)$ & & $(.379)$ & & $(.201)$ & \\
\hline \multirow[t]{2}{*}{ Arab - Other (Druze/Christian) } & $-.987 * * *$ & .37 & -.915 & .40 & .247 & 1.28 \\
\hline & $(.283)$ & & $(.521)$ & & $(.259)$ & \\
\hline
\end{tabular}




\begin{tabular}{|c|c|c|c|c|c|c|}
\hline Sex (Female) & $-.348 * * *$ & .70 & $-.284 *$ & .75 & -.017 & .98 \\
\hline & $(.079)$ & & $(.140)$ & & $(.078)$ & \\
\hline \multicolumn{7}{|l|}{ Age (Omitted: Less than 30) } \\
\hline \multirow[t]{2}{*}{$30-39$} & .190 & 1.21 & $.640 *$ & 1.90 & .069 & 1.07 \\
\hline & $(.132)$ & & $(.258)$ & & $(.127)$ & \\
\hline \multirow[t]{2}{*}{$40-49$} & $.592 * * *$ & 1.80 & $.765 *$ & 2.15 & $.325^{*}$ & 1.38 \\
\hline & $(.155)$ & & $(.300)$ & & $(.149)$ & \\
\hline \multirow[t]{2}{*}{$50-64$} & $.685 * * *$ & 1.98 & $.932 *$ & 2.55 & $.458 * *$ & 1.58 \\
\hline & $(.165)$ & & $(.309)$ & & $(.159)$ & \\
\hline \multirow[t]{2}{*}{$65+$} & $.765 * * *$ & 2.14 & $.870 *$ & 2.41 & .222 & 1.24 \\
\hline & $(.199)$ & & $(.362)$ & & $(.191)$ & \\
\hline \multicolumn{7}{|l|}{ Marital Status (Omitted: Married) } \\
\hline \multirow{2}{*}{ Divorce/Separated } & $-.471 * *$ & .62 & -.097 & .90 & $-.341 *$ & .71 \\
\hline & $(.138)$ & & $(.223)$ & & $(.135)$ & \\
\hline \multirow[t]{2}{*}{ Widowed } & $-.313^{*}$ & .73 & .183 & 1.20 & $-.319 *$ & .72 \\
\hline & $(.158)$ & & $(.240)$ & & $(.155)$ & \\
\hline \multirow[t]{2}{*}{ Single } & -.067 & .93 & .028 & 1.02 & -.222 & .80 \\
\hline & $(.127)$ & & $(.239)$ & & $(.125)$ & \\
\hline \multicolumn{7}{|l|}{$\begin{array}{l}\text { Salary (Omitted: Irrelevant; } \\
\text { Unemployed/Not in Labor Force) }\end{array}$} \\
\hline \multirow[t]{2}{*}{ INS 0-4000 } & -.046 & .95 & -.338 & .71 & -.105 & .89 \\
\hline & $(.122)$ & & $(.236)$ & & $(.118)$ & \\
\hline \multirow[t]{2}{*}{ INS 4,001-7000 } & -.092 & .91 & .049 & 1.05 & .046 & 1.04 \\
\hline & $(.122)$ & & $(.221)$ & & $(.119)$ & \\
\hline \multirow{2}{*}{ INS 7,001-More than 21,000} & $.816 * * *$ & 2.26 & .400 & 1.49 & $.701 * * *$ & 2.01 \\
\hline & $(.159)$ & & $(.270)$ & & $(.160)$ & \\
\hline \multirow[t]{2}{*}{ Self-employed, Employ Others } & $.435 *$ & 1.54 & .425 & 1.53 & $.415^{*}$ & 1.51 \\
\hline & $(.171)$ & & $(.278)$ & & $(.174)$ & \\
\hline \multirow[t]{2}{*}{ Homeowner } & $.233 * *$ & 1.26 & .180 & 1.19 & $.230 * *$ & 1.26 \\
\hline & $(.085)$ & & $(.151)$ & & $(.083)$ & \\
\hline \multicolumn{7}{|l|}{$\begin{array}{l}\text { Education (Omitted: Less than HS } \\
\text { Matriculation) }\end{array}$} \\
\hline \multirow[t]{2}{*}{ BA or higher } & $1.485 * * *$ & 4.41 & $.562 *$ & 1.75 & $.942 * * *$ & 2.56 \\
\hline & $(.124)$ & & $(.210)$ & & $(.125$ & \\
\hline \multirow[t]{2}{*}{ Matriculation - LT BA } & $.687 * * *$ & 1.98 & .234 & 1.26 & $.461^{* * *}$ & 1.58 \\
\hline & $(.088)$ & & $(.159)$ & & $(.087)$ & \\
\hline \multicolumn{7}{|l|}{$\begin{array}{l}\text { Language Proficiency (Omitted: Poorly } \\
\text { Spoken Hebrew) }\end{array}$} \\
\hline \multirow[t]{2}{*}{ Very good } & $1.276 * * *$ & 3.58 & .522 & 1.68 & $.426 * *$ & 1.53 \\
\hline & (.176) & & $(.279)$ & & $(.146)$ & \\
\hline \multirow[t]{2}{*}{ Good-fair } & $.997 * * *$ & 2.71 & .338 & 1.40 & $.327 *$ & 1.38 \\
\hline & $(.161)$ & & $(.247)$ & & $(.127)$ & \\
\hline \multicolumn{7}{|l|}{$\begin{array}{l}\text { Religiosity (Omitted: Not } \\
\text { Religious/Secular) }\end{array}$} \\
\hline Very religious & $-.787 * * *$ & .45 & $-.778 * *$ & .47 & $-.585 * * *$ & .55 \\
\hline & (.113) & & $(.221)$ & & $(.112)$ & \\
\hline Religious & $-.378 * * *$ & .68 & -.208 & .81 & -.078 & .92 \\
\hline
\end{tabular}




\begin{tabular}{|c|c|c|c|c|c|c|}
\hline & $(.092)$ & & $(.154)$ & & $(.092)$ & \\
\hline Meet Friends (Omitted: No) & & & & & & \\
\hline Less than Twice a Month & $.313^{*}$ & 1.36 & .011 & 1.00 & $\mathbf{. 2 9 6 *}$ & $\mathbf{1 . 3 4}$ \\
\hline & $(.144)$ & & $(.246)$ & & $(.136)$ & \\
\hline $1-2$ a Month & $.403^{* * *}$ & 1.49 & .108 & 1.10 & $.574^{* * *}$ & 1.77 \\
\hline & $(.121)$ & & $(.202)$ & & $(.114)$ & \\
\hline Daily & $.271^{*}$ & 1.31 & .138 & 1.12 & $.417 * * *$ & 1.51 \\
\hline & $(.123)$ & & $(.204)$ & & $(.117)$ & \\
\hline Someone to Count on (Yes) & $\mathbf{. 4 0 8 * * *}$ & $\mathbf{1 . 5 0}$ & -.170 & .84 & .168 & 1.18 \\
\hline & $(.116)$ & & $(.180)$ & & $(.106)$ & \\
\hline Intercept & -.130 & & -1.599 & & .244 & \\
\hline & $(.355)$ & & $.627)$ & & $(.331)$ & \\
\hline
\end{tabular}

$\mathrm{N}=7,190$

Significant at: *.05 **.01 ***.001

All models include dummy variables for District and "Unknown" salary.

The association between economic attributes and policy preferences is in line with our expectations. Homeowners, self-employed, and Israelis with high income express stronger support for opportunity-enhancing policies (investment in education or job creation) than for increasing welfare. As noted above, some studies reported a positive correlation between education and support for government investment in welfare. The current analysis, however, suggests that even when socioeconomic status is taken into consideration, the highly educated are less likely than those with low levels of education, to choose the category welfare provision.

Moving to the demographic variables, some findings are particularly intriguing. While it is impossible to distinguish life-cycle from cohort effects in cross-sectional data, in all three sections, and particularly in section B, the age pattern is curvilinear; the young (less than 30 years old), are more likely, and the middle-aged (50-64 years old) are the least likely, to choose "welfare provision." For example, in comparison to young Israelis, middle-aged Israelis (50-64 years old), are twice (Exp. [.685] = 1.98) as likely to choose "investment in education," than "increasing support to low income populations." Note, however, that this finding does not necessarily refute the "generational contract" theory; most middle-aged and elderly Israelis are strongly supportive of investment in education and job creation-policy frameworks that almost exclusively benefit the young.

The ethnic coefficients reveal clear ethnic/nationality variation in policy preferences. In comparison to first-generation Ashkenazi (the omitted category), all the ethnic/national groups, but particularly Arab citizens and recent immigrants from the former USSR - two economically 
vulnerable populations - are less likely to choose "investment in education" over "providing welfare to the poor." Looking at section B ("Raising taxes among the rich"), we see that in addition to Muslims, only the "native born of Israeli and mixed ethnic origin" coefficient exerts (negative) significant results (Exp. [-.765] = .47). The results presented in section C ("Job creation") reveal that in a clear departure from findings seen in sections A and B, the Muslim population generally views policies that create new workplaces as preferable to welfare provision; Muslims are almost twice as likely (Exp. [.626] = 1.87) as first-generation Ashkenazi Jews to select "Job creation." Given the high rates of unemployment and poverty experienced by this population and their residential concentration in the peripheral regions of the state, it is not surprising that job creation is viewed by Muslims as a much-needed remedy for socioeconomic inequality. Finally, even after socioeconomic characteristics are taken into account, Israeli women are more likely than men to choose "welfare provision" over investment in education or raising taxes (the coefficient is not statistically significant in section $\mathrm{C}$ ). This finding could be attributed to gender role socialization (Svallfors 1997; Konrad and Hartmann 2001; Kravitz and Platania 1993), and the greater reliance of Israeli women on government services (Swirski et al 2001).

The roles acculturation, social capital, and religiosity play in shaping people's policy preferences are particularly evident in sections A and C. Language (Hebrew) proficiency, which is used as a proxy for acculturation, is positively correlated with the opportunity-enhancing policies of "Investment in education" and "Job creation" (see also Branton 2007). While not statistically significant, the effect of the language variables is also positive in section B. A similar pattern is found in the measure of social interactions with friends, which is positively correlated with the two opportunity-enhancing policies. For example, respondents who meet or talk with friends every day are more likely than respondents who don't meet friends at all to support job creation over welfare (Exp. [.417] = 1.51). Respondents who gave a positive answer to the question "having someone to count on in times of need" are 50\% more likely than those who answered "No," to choose "investment in education" over "welfare provision" (Exp. [.408] $=1.50$ ). Level of religiosity reveals a negative sign in all three sections, indicating that those who report a high level of religiosity are more likely to support "welfare provision" than any other policy categories. In the Israeli context, this finding is not surprising. Analysis not shown in this paper revealed that the variable religiosity exerts a significant effect among Jews but not 
Arabs, a pattern reflecting the greater reliance of ultra-Orthodox Jews on welfare, a policy that is a contentious issue in Israeli political and public discourse.

Because in Israel, acculturation, religiosity and social capital are closely linked to economic and demographic characteristics, such as immigration status, national origin, fertility, and education, Appendix B presents results from hierarchical multinomial analysis. The table reports findings from two models: A baseline model which excludes the social indicators and the full model (also reported in Table 2) that includes them. The objective of this analysis is to get a clearer picture of the relationships between the three sets of explanatory variables and to assess the extent to which social attributes mitigate the association between policy preferences and the demographic and socioeconomic characteristics. The results reveal that the addition of social indicators to the baseline model substantially alters the demographic and socioeconomic coefficients. For some variables - for example, number of children (sections A and B), secondgeneration Mizrahi (section B), immigrants from FSU (sections B and C), age category 30-39 (section A) and single (non-married) Israelis (section C) - the effect of the coefficients is no longer statistically significant after the social variables are introduced. And for many variables, while still significant, the magnitude of the coefficients is altered. Thus, for example, the magnitude of the key socioeconomic indicators self-employment, homeownership, salary, education, and number of earners substantially diminished. These findings imply that the social indicators assimilation, religiosity and social networks, intervene in, and explain part of, the relationship between socioeconomic status and policy preferences. A similar pattern is seen for most demographic characteristics including health status, number of children, household size, and gender. The effects of two of the key demographic variables - age and ethnic/national origin-merit attention. The inclusion of the social indicators in section A uncovers a polarized age pattern that separates those over 50, who express strong support for investment in education, from younger (under 40) Israelis. In most ethnic/national categories in all the three sections, the ethnic/national coefficients are reduced when social factors are introduced. For example, once the social indicators are introduced into the baseline model (A) the effect of "Immigrants from the Former Soviet Union" is diminished by a quarter from $B=-1.38$ to $B=-.105$. This change suggests that ethnic differences in social characteristics explain part of the ethnic gaps in policy preferences. In section C, however, the "Arab - Muslim" coefficient is altered from weak and statistically insignificant (baseline model), to positive and significant (full model). In other words, the exclusion of social factors from a model predicting policy preferences (baseline 
model), seems to mask the strong support among Muslims for job creation as a means to reduce gaps. Only when the social indicators are introduced (full model), this preference among Muslims is surfaced.

\section{Marginal Effects}

While illuminating, the findings reported in Table 2 answered the key research questions by focusing on level of support for three policies in contrast to the reference category "support to low income populations." However, the interpretation of the coefficients leaves room for several possible explanations vis a vis the specific policy preferences of each socioeconomic or demographic indicator. For example, a negative sign in the coefficient "female" vs. "male" in column 1 (Education) could indicate one of several patterns: (1) that among women, support for education is lower but support for welfare (the reference category) is higher than among men; (2) that support for both Education and Welfare is lower among women than men, but women's support for Education is much weaker than their support for welfare; or (3) that women support both Education and Welfare more than men do, but their support for Education is much weaker than their support for Welfare compared to the men. All these scenarios would yield a negative sign for the "female" coefficient.

Table 3 Multinomial Regression of Policy Preferences (Standard Errors in Parentheses): Marginal Effects

\begin{tabular}{|c|c|c|c|c|}
\hline & A (Education) & (B) Taxes & (C) Job Creation & (D) Welfare \\
\hline \multirow[t]{2}{*}{ Number of children } & .006 & -.002 & $-.010 *$ & $.007 *$ \\
\hline & $(.005)$ & $(.002)$ & $(.004)$ & $(.003)$ \\
\hline \multirow[t]{2}{*}{ Health (1 Low - 4 High) } & $.032 * * *$ & $-.008^{*}$ & .000 & $-.025 * * *$ \\
\hline & $(.003)$ & $(.003)$ & $(.008)$ & $(.006)$ \\
\hline \multirow[t]{2}{*}{ Number of earners } & .003 & .006 & .008 & $-.019 * *$ \\
\hline & $(.008)$ & $(.003)$ & $(.007)$ & $(.006)$ \\
\hline \multirow[t]{2}{*}{ Household size } & -.009 & -.003 & .000 & $.012 * * *$ \\
\hline & $(.005)$ & $(.002)$ & $(.005)$ & $(.003)$ \\
\hline \multicolumn{5}{|l|}{ Ethnicity } \\
\hline \multirow[t]{2}{*}{ Israel - Ashkenazi origin } & $-.051 *$ & -.004 & .001 & $.054 *$ \\
\hline & $(.025)$ & $(.012)$ & $(.029)$ & $(.027)$ \\
\hline \multirow[t]{2}{*}{ Israel - Israeli and mixed origin } & $-.055^{* *}$ & -.009 & -.026 & $.092 * * *$ \\
\hline & $(.022)$ & $(.010)$ & $(.024)$ & $(.022)$ \\
\hline \multirow[t]{2}{*}{ Israel - Mizrahi origin } & $-.055 *$ & -.000 & -.035 & $.091 * * *$ \\
\hline & $(.023)$ & $(.010)$ & $(.026)$ & $(.023)$ \\
\hline \multirow[t]{2}{*}{ Immigrant - Mizrahi origin } & $-.065 * *$ & .000 & -.011 & $.076^{* * *}$ \\
\hline & $(.024)$ & $(.010)$ & $(.026)$ & $(.023)$ \\
\hline
\end{tabular}




\begin{tabular}{|c|c|c|c|c|}
\hline Immigrant - Former SU & $-.163 * * *$ & .001 & $.073 * *$ & $.088 * * *$ \\
\hline & $(.023)$ & $(.010)$ & $(.024)$ & $(.022)$ \\
\hline \multirow[t]{2}{*}{ Arab-Muslim } & $-.294 * * *$ & -.021 & $.284 * * *$ & .032 \\
\hline & $(.030)$ & $(.014)$ & $(.028)$ & $(.025)$ \\
\hline \multirow[t]{2}{*}{ Arab - Other (Druze/Christian) } & $-.215 * * *$ & -.024 & $.189 * * *$ & .050 \\
\hline & $(.040)$ & $(.019)$ & $(.037)$ & $(.033)$ \\
\hline \multirow[t]{2}{*}{ Female } & $-.063 * * *$ & -.005 & $.044 * * *$ & $.024 *$ \\
\hline & $(.011)$ & $(.005)$ & $(.011)$ & $(.009)$ \\
\hline \multicolumn{5}{|l|}{ Age } \\
\hline \multirow[t]{2}{*}{$30-39$} & .018 & $.022 *$ & -.019 & -.021 \\
\hline & $(.019)$ & $(.009)$ & $(.019)$ & $(.015)$ \\
\hline \multirow[t]{2}{*}{$40-49$} & $.066 * *$ & .016 & -.018 & $-.063 * * *$ \\
\hline & $(.023)$ & $(.011)$ & $(.022)$ & $(.018)$ \\
\hline \multirow[t]{2}{*}{$50-64$} & $.065 * *$ & .019 & -.005 & $-.079 * * *$ \\
\hline & $(.024)$ & $(.011)$ & $(.024)$ & $(.019)$ \\
\hline \multirow[t]{2}{*}{$65+$} & $.112 * * *$ & .019 & $-.063^{*}$ & $-.068 * *$ \\
\hline & $(.030)$ & $(.013)$ & $(.030)$ & $(.023)$ \\
\hline \multicolumn{5}{|l|}{ Marital Status } \\
\hline \multirow[t]{2}{*}{ Divorce/Separated } & $-.051 *$ & .009 & -.009 & $.051 * *$ \\
\hline & $(.021)$ & $(.008)$ & $(.021)$ & $(.016)$ \\
\hline \multirow[t]{2}{*}{ Widowed } & -.026 & .017 & -.029 & $.038 *$ \\
\hline & $(.026)$ & $(.009)$ & $(.026)$ & $(.018)$ \\
\hline \multirow[t]{2}{*}{ Single } & -.013 & .005 & $-.038 *$ & .018 \\
\hline & $(.019)$ & $(.009)$ & $(.019)$ & $(.015)$ \\
\hline \multicolumn{5}{|l|}{ Salary } \\
\hline \multirow[t]{2}{*}{ INS 0-4,000 } & .009 & -.011 & -.011 & .012 \\
\hline & $(.019)$ & $(.009)$ & $(.119)$ & $(.014)$ \\
\hline \multirow[t]{2}{*}{ INS 4,001-7,500 } & -.025 & .002 & .020 & .001 \\
\hline & $(.018)$ & $(.008)$ & $(.018)$ & $(.014)$ \\
\hline \multirow[t]{2}{*}{ INS 7,001 to More than 21,000} & $.070 * * *$ & -.007 & .036 & $-.098 * * *$ \\
\hline & $(.020)$ & $(.009)$ & $(.021)$ & $(.020)$ \\
\hline \multirow[t]{2}{*}{ Self-employed, Employs Others } & .028 & .003 & .024 & $-.057 * *$ \\
\hline & $(.020)$ & $(.009)$ & $(.022)$ & $(.022)$ \\
\hline \multirow[t]{2}{*}{ Homeowner } & .015 & -.000 & .015 & $-.030 * *$ \\
\hline & $(.012)$ & $(.005)$ & $(.013)$ & $(.010)$ \\
\hline \multicolumn{5}{|l|}{ Education } \\
\hline \multirow[t]{2}{*}{ BA or Higher } & $.173 * * *$ & $-.016^{*}$ & -.000 & $-.156 * * *$ \\
\hline & $(.016)$ & $(.007)$ & $(.017)$ & $(.015)$ \\
\hline \multirow[t]{2}{*}{ Matriculation and LT BA } & $.077 * * *$ & -.009 & .005 & $-.073 * * *$ \\
\hline & $(.013)$ & $(.006)$ & $(.013)$ & $(.010)$ \\
\hline \multicolumn{5}{|l|}{ Language Proficiency } \\
\hline Very Good & $.196 * * *$ & -.006 & $-.080 * *$ & $-.109 * * *$ \\
\hline & $(.029)$ & $(.010)$ & $(.025)$ & $(.018)$ \\
\hline Goof-Fair & $.155 * * *$ & -.008 & $-.063 * *$ & $-.084 * * *$ \\
\hline & $(.027)$ & $(.009)$ & $(.023)$ & $(.016)$ \\
\hline Religiosity & & & & \\
\hline Very Religious/Religious & $-.072 * * *$ & -.009 & -.010 & $.092 * * *$ \\
\hline & $(.017)$ & $(.008)$ & $(.017)$ & $(.013)$ \\
\hline Not So Religious & $-.063 * * *$ & -.000 & $035 * *$ & $.029 * *$ \\
\hline
\end{tabular}




\begin{tabular}{|c|c|c|c|c|}
\hline & $(.012)$ & $(.005)$ & $(.013)$ & $(.011)$ \\
\hline Meet Friends & & & & \\
\hline Less than Twice a Month & .026 & -.009 & .021 & $\mathbf{- . 0 3 8}^{*}$ \\
\hline & $(.024)$ & $(.009)$ & $(.023)$ & $(.016)$ \\
\hline 1-2 a Month & .007 & -.010 & $.066^{* * *}$ & $-.063^{* * *}$ \\
\hline & $(.020)$ & $(.007)$ & $(.019)$ & $(.013)$ \\
\hline Daily & .000 & -.005 & $.050^{*}$ & $-.045^{* *}$ \\
\hline Someone to Count on & $(.021)$ & $(.007)$ & $(.020)$ & $(.013)$ \\
\hline & $\mathbf{. 0 6 4 * * *}$ & $-.016^{*}$ & -.014 & $-.033^{* *}$ \\
\hline
\end{tabular}

$\mathrm{N}=7,190$

Significant at: $* .05 * * .01 * * * .001$

All models include dummy variables for District and "Unknown" salary.

To provide a more complete picture of the Israeli public preferences, Table 3 reports the marginal effects of the multinomial analysis. ${ }^{3}$ The marginal effects approach enables us to present an intuitive explanation for public support for each policy category relative to the other three options. ${ }^{4}$ The marginal effect results accentuate our previous results. The clear contrast between support for investment in education on one hand and support for spending on welfare on the other hand is evident in some of the demographic and socioeconomic variables. Holding all other variables equal, Israelis with a high level of education are $17.3 \%$ more likely to choose "investment in education," but are $15.6 \%$ less likely to choose "increase support for low-income populations" than are Israelis with a low level of education. The ethnic/national categories reveal interesting patterns; among Arabs, the relatively weak support for education is counterbalanced by a strong support for job creation; in contrast to first generation Ashkenazi Jews, Muslims are 29.7\% less likely to choose education and $28.4 \%$ more likely to choose job creation. To a lesser degree, weak support for investment in education is also visible among Mizrahi Jews and FSU immigrants, while FSU immigrants express strong support for both Job creation and welfare. As expected, language proficiency is associated with strong support for investment in education but Table 3 also shows a weaker support among Israelis with "very

\footnotetext{
${ }^{3}$ Marginal effect coefficients measure the change in a dependent variable (Y) that is produced by a one unit change in an independent variable (Xk). In this paper the AME (Average Marginal Effect) method, was used. The AME, which computes a marginal effect for each case and then average the effects, is the default methods for the margins command in STATA, and is considered a robust method that provides an accurate representation of how changes in the independent variables affect the probability of choosing one outcome category of a dependent variable over the other categories (Cameron and Trivedi 2010).

${ }^{4}$ Note, for example, the positive effect for the elderly (65 or older) coefficient in Table 2 column B, (Increasing taxes), but the lack of significant effect for the same coefficient in Table 3. This discrepancy suggests that the positive effect in Table 2 was a product of the a weak support for welfare provision (6.7\%), rather than a strong preference for tax increase, among the elderly.
} 
good" level of spoken Hebrew (vs. poor language proficiency) for job creation and welfare. Relative to secular Israelis, the very religious are more supportive of welfare (9.1\%) and express weaker support for education (-7.3\%). Holding all other variables equal, meeting with friends is correlated with weak support for welfare provision, and the probability that those who have "someone to count on" will choose the category investment in education is $6.4 \%$ higher in comparison to Israelis who answered "no" to this question.

\section{DISCUSSION AND CONCLUSIONS}

Social and economic inequality in Israel is extreme and multifaceted. Not only is the level of inequality high — both historically and relative to other industrial societies — but it intertwines with various social and demographic attributes such as ethnicity, national origin, religiosity and immigration status. Drawing on the relevant literature and the distinct nature of Israel's stratification system, the key objective of the study was to describe and explain the key social and demographic attributes that form public support for specific opportunity- and outcomebased redistributive policies in contemporary Israeli society.

The majority of the population in Israel supports opportunity-enhancing remedies to inequality and many cite investment in education as the preferred policy. This finding is in line with recent evidence showing a general decline in the collectivist and egalitarian ethos that characterized Israel's early years - a historical shift toward a stronger cultural emphasis on merit and economic individualism, and an overall retraction from public welfare provision (Bar-On et al. 1999; Ram 2000; see Lewin Epstein et al. 2003).

While the economic self-interest theory is a plausible explanation for the stronger support expressed by the financially-better-off segments of the population for opportunity enhancing policies, in a diverse and highly unequal society, individual demographic backgrounds and social factors emerge as important determinants of redistributive policy preferences.

More than six decades after the establishment of the state, redistributive policy preferences are shaped by ethnic and national affiliations that cut across class lines. While the Mizrahi-Ashkenazi divide among second generation Israelis is trivial (Table 3), the disparity between two ethnic/national origin categories - first-generation Ashkenazi Jews and Muslim Arabs - stands out as an extreme example of distinct policy preferences. First-generation Ashkenazi Jews, a group to which the founding fathers of the state belong, and still has the 
highest political and socioeconomic power (Haberfeld and Cohen 2007) displays the lowest level of support for welfare provision to the poor and the strongest support for the opportunityenhancing policy investment in education. Muslims, on the other hand, express an exceptionally robust preference for job creation as a key means to reduce socioeconomic gaps. It is not surprising that in a community characterized by high level of poverty, social segregation, and a lower degree of attachment to the Jewish state, economic independence through job creation is viewed as a preferred path for social equality. Ethnic/national origin is closely associated with acculturation and assimilation of minority group members into the dominant culture. Previous studies have linked acculturation of minority group members to lower trust in government programs and diminished support for welfare provisions to families in need (Michelson 2001; Branton 2007). The Israeli data, which presented respondents with four policy options, reveal that as a measure of acculturation, language proficiency is not only associated with weak support for welfare, but it is also correlated with strong support for investment in education-a policy choice that is common among the dominant groups in Israeli society (Ashkenazi, male, highly educated, secular) and reflects confidence in the notion of meritocracy and economic individualism. The findings indicate that an improvement in language proficiency among immigrants from the FSU and Israeli Arabs - the two groups with the lowest level of Hebrew proficiency - would lead to a shift in attitudes towards a greater support for investment in education.

The sharp difference in policy preferences between the secular and the religious reveals a deep divide within the contemporary Israeli society. In contrast to findings from studies in Europe (Stegmuller et al. 2011), religious respondents in Israel express stronger, not weaker, support for government spending on support for the poor as a means to reduce economic gaps. As mentioned above, in Israel religion is strongly embedded in the political sphere and religious parties are playing an important role in domestic politics (Waxman 2004). Religious families have on average more children, and many ultra-orthodox Jews live in poverty and benefit from social assistance programs as a main source of livelihood (Levy et al. 2004). This association between religiosity and poverty could explain the weak support for spending on welfare among secular Israelis; As Gilens's (1999) work demonstrated, people's perceptions about the demographic makeup of the poor and the view of the poor as "undeserving" has a strong impact on public opposition to invest in social welfare programs. 
One's policy preferences are also embedded in access to social and economic resources through actual or potential social contacts. The findings reported above clearly show that as determinants of redistributive policy preferences, social capital in the form of contact with friends and having people to count on in times of need should be taken more seriously by social scientists and policy makers. The fact that measures such as acculturation, religiosity and social capital are associated with economic status and demographic characteristics, suggest that the inclusion of these measures in future research on policy preferences could yield a more complete and robust picture of public opinion and the determinants of public support for redistributive policies. 


\section{References}

Al-Haj, Majid. 1995. "Education, Empowerment and Control: The Case of the Arabs in Israel NY," SUNY Press.

Bar-On, D., E. Orr, S. Sagy. 1999. "Individualism and Collectivism in Israeli Society:

Comparing Religious and Secular High-School Students," Human Relations, 52 (3)

Birenbaum-Carmeli, D. 2009. "The Politics of 'The Natural Family' in Israel: State Policy and Kinship Ideologies," Social Science and Medicine, 69: 1018-1024.

Blekesaune, M. and J. Quadagno. 2003. "Public Attitudes Toward Welfare State Policies: A Comparative Analysis of 24 Nations," European Sociological Review, Vol. 19, No. 5: 415-427.

Bobo, L., 1991." Social Responsibility, Individualism, and Redistributive Policies," Sociological Forum, 6 (1): 71-92.

Bobo, L. and J. Kluegel. 1993. “Opposition to Race-Targeting: Self-Interest, Stratification Ideology, or Racial Attitudes?,” American Sociological Review, 58:443-64.

Branton, R.P., 2007. "Latino Attitudes Toward Various Areas of Public Policy: The Importance of Acculturation," Political Research Quarterly, 60: 293-303.

Brooks Clem and Jeff Manza. 2006. Social Policy Responsiveness in Developed Democracies. American Sociological Review. 71 (3): 474-494

Burstein Paul. 1998. Bringing the Public Back in: Should Sociologists Consider the Impact of Public Opinion on Public Policy? Social Forces. 77 (1): 27-62.

Busemeyer, M.R., A. Goerres, and S. Weschle. 2009. "Attitudes Towards Redistributive Spending in an Era of Demographic Ageing: The Rival Pressures from Age and Income in 14 OECD Countries," Journal of European Social Policy, 19 (3):195-212.

Cameron, C.A., and P.K. Trivedi. 2010 "Stata Version 11 and Microeconometrics Using Stata," http://www.stata.com/bookstore/pdf/mus11.pdf, Accessed September 9, 2014.

2009. "Microeconometrics Using Stata," College Station (TX), Stata Press.

Central Bureau of Statistics, 2013. "Israel in Figures," Central Bureau of Statistics. http://cbs.gov.il/www/publications/isr_in_n13e.pdf, Accessed September 8, 2014

Cohen, Y., and Y. Haberfeld. (1998). Second Generation Jewish Immigrants in Israel: Have the Ethnic Gaps in Schooling and Earnings Declined? Ethnic and Racial Studies. 21: 507528.

Cohen, Y., Y. Haberfeld, and T. Kristal. 2007. "Ethnicity and Mixed Ethnicity: Educational Gaps among Israeli-born Jews," Ethnic and Racial Studies, 30: 896-917 
Cohen, N., S. Mizrahi, and F. Yuval. 2011. "Public Attitudes Towards the Welfare State and Public Policy: Israel 2008," Israel Affairs, 17: 621-643.

Cordova, A. 2011. "The Role of Social Capital in Citizen Support for Government Action to Reduce Economic Inequality,” International Journal of Sociology, Vol. 41, No. 2: 28-49

Edlund, J. 1999. "Trust in Government and Welfare Regimes: Attitudes to Redistribution and Financial Cheating in the USA and Norway," European Journal of Political Research, 35: 341-370.

Endeweld, M., A. Fruman, N. Barkali, and D. Gottlieb. 2008. "Poverty and Social Gaps; Annual Report," National Insurance Institute. http://www.btl.gov.il/English\%20Homepage/Publications/Annual\%20Surveys/Pages/default.as px, Accessed September 8, 2014

Friedlander, D., B.S. Okun, Z.Eisenbach, and L.L. Elmakias. 2002. "Immigration, Social Change and Assimilation: Educational Attainment among Birth Cohorts of Jewish Ethnic Groups in Israel, 1925-29 to 1965-69," Population Studies, 56(2):135-150.

Ghanem, A. 2001. “The Palestinian-Arab Minority in Israel,1948-2000," State University of New York Press.

Gilens, M. 1999. "Why Americans Hate Welfare: Race, Media, and the Politics of Antipoverty Policy," Chicago: Chicago Press.

Haberfeld, Y. and Y. Cohen. 1998. "Earnings of Native Born Arab and Jewish Men in Israel 1987-1993," Research in Social Stratification and Mobility, 16: 69-88. 2007. "Gender, Ethnic, and National Earnings Gaps in Israel: the Role of Rising Inequality,” Social Science Research, 36: 654-672.

Hasenfeld, Y. and J.A. Rafferty. 1989. "The Determinants of Public Attitudes toward the Welfare State,” Social Forces, Vol. 67, No. 4: 1027-1048

Jackman, Mary R., and Michael J. Muha. 1984. Education and Intergroup Attitudes: Moral Enlightenment, Superficial Democratic Commitment, or Ideological Refinement? American Sociological Review 49:751-769.

Kravitz, D. A. and J. Platania.1993. "Attitudes and Beliefs about Affirmative Action: Effects of Target and of Respondent Sex and Ethnicity," Journal of Personality and Social Psychology, 78: 928-938.

Kluegel James R., Elliot R. Smith, 1983. Affirmative Action attitudes: effects of self-interest, Racial Affect and Stratification beliefs on Whites Views" Social forces 61: 797-824.

Levy, S., H. Levinsohn, and E. Katz. 2004. "The Many Faces of Jewishness in Israel," in Rebhun Uzi and Chaim I. Waxman (eds.). Jews in Israel; Contemporary Social and Cultural Patterns. Brandeis University Press. Pp. 265-285. 
Lewin-Epstein, N. and M. Semyonov. 1994. "Sheltered Labor Markets, Public Sector Employment, and Socioeconomic Returns to Education of Arabs in Israel," The American Journal of Sociology, 100 (3): 622-651

Lewin-Epstein N., Y. Elmelech, and M. Semyonov. 1997. "Ethnic Inequality in HomeOwnership and the Value of Housing: The Case of Immigrants to Israel," Social Forces, 75(4): 1439-62.

Lewin-Epstein, N. and M. Semyonov. 2000. "Migration, Ethnicity and Inequality: Homeownership in Israel," Social Problems, 47: 425-444.

Lewin Epstein, N., A. Kaplan, and A. Levanon. 2003. "Distributive Justice and Attitudes Toward the Welfare State,” Social Justice Research, 16(1): 1-27.

Manski Charles F., J. Mayshar. 2002. "Private and Social Incentives for Fertility: Israeli Puzzles," NBER Working Paper, http://www.nber.org/papers/w8984, Accessed September 8, 2014.

McCall, L. and L. Kenworthy. 2009. “Americans' Social Policy Preferences in the Era of Rising Inequality Source," Perspectives on Politics, Vol. 7, No. 3: 459-484

McClosky, H. and A. Brill. 1983. "Dimensions of Tolerance," Russell Sage

Anson, J. and A. Meir. 1996. "Religiosity, Nationalism and Fertility in Israel," European Journal of Population, 12, 1-25

Miech, R., F. Pampel, J. Kim, and R.G. Rogers. 2011. "The Enduring Association Between Education and Mortality: The Role of Widening and Narrowing Disparities," American Sociological Review, 76: 913-934

Michelson M.R. 2001. "Political Trust Among Chicago Latinos," Journal of Urban Affairs, 23: 323-334.

2003. "The Corrosive Effect of Acculturation: How Mexican Americans Lose Political Trust," Social Science Quarterly, 84 (4): 918-933

Neckerman, K.M. and F. Torche. 2007. "Inequality: Causes and Consequences," Annual Review of Sociology, 33: 335-357.

OECD. 2013. "Crisis Squeezes Income and Puts Pressure on Inequality and Poverty," http://www.oecd.org/els/soc/OECD2013-Inequality-and-Poverty-8p.pdf, Accessed September 8,2014

Oh, E., C. Choi, H. Neville, C. Anderson, and J. Landrum-Brown. 2010. "Beliefs About Affirmative Action: A Test of the Group Self-Interest and Racism Beliefs Model," Journal of Diversity in Higher Education, 3(3): 163-176. 
Okun, B.S. and D. Friedlander. 2005. "Educational Stratification Among Arabs and Jews in Israel: Historical Disadvantage, Discrimination, and Opportunity," Population Studies, Vol. 59, No. 2: 163-180

Perlmann J., and Y. Elmelech. 2010. "'Immigrant Parents' Attributes Versus Discrimination: New Evidence in the Debate about the Creation of Second Generation Educational Outcomes in Israel," Working paper 633, Levy Economics Institute of Bard College.

Persson, T. and G. Tabellini. 1994. "Is Inequality Harmful for Growth?," The American Economic Review, 84 (3): 600-621.

Ram, U. (2000). "The Promised Land of Business Opportunities: Liberal Post-Zionism in the Global Age," In: Shafir, G., and Peled, Y. (eds.), The New Israel: Peacemaking and Liberalization, Westview. Press, Boulder, CO, pp. 217-240

Sa'di, A.H. 1995. "Incorporation Without Integration: Palestinian-Citizens in Israel's Labour Market," Sociology, 29 (3): 429-451.

Semyonov, M. and Y. Cohen. 1990. "Ethnic Discrimination and the Income of Majority-Group Workers," American Sociological Review, 55 (1): 107-114.

Shalev, M.. 2007. "The Welfare State Consensus in Israel: Placing Class Politics in Context," In Social Justice. "Legitimacy and the Welfare State," edited by Steffen Mau and Benjamin Veghte. Ashgate.

Shelton, J. and G. Wilson. 2009. "Race, Class, and the Basis of Group Alignment: An Analysis of Support for Redistributive Policy Among Privileged Blacks," Sociological Perspectives, 52: 385- 408.

Spilerman S., Y. Elmelech. 2003. "Israeli Attitudes about Inter Vivos Transfers," In Bengtson, V. L., and Lowenstein, A. (Eds.)" Global Aging and Challenges to Families," Hawthorne, NY: Aldine de Gruyter.

Spilerman S. 2004. "Young Couples in Israel: The Impact of Parental Wealth on Early Living Standards," American Journal of Sociology, 110(1): 92-122.

Stegmueller, D., P. Scheepers, S. Robteutscher, and E. de Jong. 2012. "Support for Redistribution in Western Europe: Assessing the Role of Religion," European Sociological Review, 28 (4): 482-497

Street, D. and J.S. Cossman. 2006. "Greatest Generation or Greedy Geezers? Social Spending Preferences and the Elderly," Social Problems, 53 (1): 75-96

Sullivan, J.L., J. Piereson, and G.E. Marcus. 1982. "Political Tolerance and American Democracy," University of Chicago Press.

Svallfors, S. 1997. "Worlds of Welfare and Attitudes to Redistribution: A Comparison of Eight Western Nations," European Sociological Review, 13 (3): 283-304. 
Swirski, S., E. Konur, Y. Yecheskel, and B. Swirski. 2001. "Women in the Labor Market of the Welfare State in Israel," Tel Aviv: Adva Center.

Warren, M.R., J.P. Thompson, and S. Saegert. 2001. "The Role of Social Capital in Combating Poverty," In Susan Saegert, J. Phillip Thompson, and Mark R. Warren (Eds.) "Social capital and poor communities," New York: Russell Sage Foundation: 1-30

Waxman, C.I. 2004. "Religion in the Israeli Public Square," In Rebhun Uzi and Chaim I. Waxman (eds.). "Jews in Israel; Contemporary Social and Cultural Pattern," Brandeis University Press. Pp. 221-243.

Wilson, T.C. 2001. "'Americans' Views on Immigration Policy: Testing the Role of Threatened Group Interests," Sociological Perspectives, 44(4), 485-501.

Zilberfarb, B. 2005. "From Socialism to Free Market - The Israeli Economy 1948-2003," Israel Affairs, 11 (1): 12-22. 


\section{APPENDIX A: DEFINITION OF VARIABLES}

\begin{tabular}{|c|c|}
\hline Dependent variable: & \\
\hline Views about Redistributive Policies & $\begin{array}{l}\text { "In your opinion, what action should the State take } \\
\text { in order to reduce the gaps in society?" } \\
\text { (1) "Invest in education," } \\
\text { (2) "Increase allowances and support to the lower- } \\
\text { income populations" } \\
\text { (3) "Encourage employment and creation of new } \\
\text { workplaces" } \\
\text { (4) "Raise taxes among the higher-income } \\
\text { populations." }\end{array}$ \\
\hline \multicolumn{2}{|l|}{ Independent Variables: } \\
\hline Number of Children Born & Ranges from " 0 " to " $7+$ " \\
\hline Health Status & $\begin{array}{l}\text { "How is your health, overall?" } \\
\text { Ranges from } 1 \text { "not good at all" to } 4 \text { "very good }\end{array}$ \\
\hline Number of Earners & Ranges from 0 to 4 \\
\hline Household size & Ranges from "0" to " $7+$ " \\
\hline Ethnic/National Origin: & $\begin{array}{l}\text { Eight categories: } \\
\text { (1)Ashkenazi immigrant } \\
\text { (2) Second generation Ashkenazi } \\
\text { (3) Mizrahi immigrant } \\
\text { (4) Second generation Mizrahi } \\
\text { (5) Israeli born to Israeli/mixed ethnic origin } \\
\text { (6) New immigrant from the Former USSR (FSU); } \\
\text { (7) Arab -Muslim; (8) Arab -Other. }\end{array}$ \\
\hline Gender & 1- Female 0- Male \\
\hline Age categories & $\begin{array}{l}\text { (1) Less than } 30 \text {; (2) 30-39; (3) 40-49; (4) 50-64; } \\
\text { (5) } 65+\end{array}$ \\
\hline Marital status & $\begin{array}{l}\text { (1) Married (2) Divorced/Separated (3) Widowed } \\
\text { (4) Single (NM) }\end{array}$ \\
\hline Salary & $\begin{array}{l}\text { Personal gross monthly income in INS from work } \\
\text { (1) No salary (2) Less than } 1,500 \text { NIS to } 3,000 \text { NIS } \\
\text { (3)NIS 3,001-6,000 (4)NIS 6,001-High (5) } \\
\text { Unknown (No data available). }\end{array}$ \\
\hline Self-Employed / Employ workers & 1 - Self-employed $0-$ No \\
\hline Homeowner & $0-$ Not owning a home \\
\hline Education & $\begin{array}{l}\text { (1) Less than matriculation certificate } \\
\text { (2) Matriculation certificate and more but less than } \\
\text { BA (3) BA or higher (MA, PHD). }\end{array}$ \\
\hline
\end{tabular}




\begin{tabular}{|l|l|}
\hline District & $\begin{array}{l}\text { (1) Jerusalem; (2) northern district; (3)Haifa } \\
\text { district; (4)central district; } \\
\text { (5) Tel Aviv district; (6) Southern district; (7) West } \\
\text { bank district. }\end{array}$ \\
\hline Language(Hebrew) Proficiency & $\begin{array}{l}\text { (1) Very good level of spoken Hebrew (2) Fair } \\
\text { level of } \\
\text { spoken Hebrew (3) Poor level/no knowledge of } \\
\text { spoken Hebrew }\end{array}$ \\
\hline Religiosity & $\begin{array}{l}\text { (1) Very religious and religious (2)- Not so } \\
\text { religious/traditional (3) Not religious/Secular }\end{array}$ \\
\hline Friendship: Meet Friends & $\begin{array}{l}\text { (1) No; (2) 1-2 a week; (3)1-2 a month; (4) Less } \\
\text { than 2 a month }\end{array}$ \\
\hline People to count on in times of trouble & \begin{tabular}{l}
1 Yes 0 - No \\
\hline
\end{tabular} \\
\hline
\end{tabular}


APPENDIX B: MULTINOMIAL REGRESSION OF POLICY PREFERENCES (STANDARD ERRORS IN PARENTHESES) BASELINE (B) AND FULL (F) MODELS

\begin{tabular}{|c|c|c|c|c|c|c|}
\hline & \multicolumn{2}{|c|}{ (A) Education } & \multicolumn{2}{|c|}{ (B) Taxes } & \multicolumn{2}{|c|}{ (C) Job Creation } \\
\hline & $\mathrm{B}$ & $\mathrm{F}$ & $\mathrm{B}$ & $\mathrm{F}$ & $\mathrm{B}$ & $\mathrm{F}$ \\
\hline \multirow[t]{2}{*}{ Children } & $-.057 *$ & -.021 & $-.131 *$ & -.088 & $-.112 * *$ & $-.072 *$ \\
\hline & $(.029)$ & $(.031)$ & $(.053)$ & $(.055)$ & $(.028)$ & $(.029)$ \\
\hline \multirow[t]{2}{*}{ Health (1 Low) } & $.314^{* *}$ & $.253 * *$ & -.024 & .036 & $.183 * *$ & $.156^{*}$ \\
\hline & $(.050)$ & $(.052)$ & $(.086)$ & $(.088)$ & $(.048)$ & $(.050)$ \\
\hline \multirow[t]{2}{*}{ \# earners } & $.169 *$ & $.127 *$ & $.295^{*}$ & $.267 *$ & $.169 * *$ & $.137 *$ \\
\hline & $(.051)$ & $(.052)$ & $(.094)$ & $(.095)$ & $(.050)$ & $(.049)$ \\
\hline \multirow[t]{2}{*}{ Household size } & $-.144 * *$ & $-.104^{*}$ & $-.175^{*}$ & $-.157 *$ & $-.092 *$ & $-.072 *$ \\
\hline & $(.032)$ & $(.033)$ & $(.062)$ & $(.062)$ & $(.030)$ & $(.031)$ \\
\hline \multicolumn{7}{|l|}{ Ethnicity } \\
\hline \multirow[t]{2}{*}{ Israel - Ashkenazi } & $-.424 *$ & $-.486^{*}$ & -.403 & -.422 & -.333 & -.319 \\
\hline & $(.207)$ & $(.211)$ & $(.338)$ & $(.344)$ & $(.218)$ & $(.222)$ \\
\hline \multirow[t]{2}{*}{ Israel (is+mix) } & $-.808 * *$ & $-.728 * *$ & $-.812 *$ & $-.765^{*}$ & $-.706 * *$ & $-.624 * *$ \\
\hline & $(.172)$ & $(.176)$ & $(.289)$ & $(.295)$ & $(.179)$ & $(.184)$ \\
\hline \multirow[t]{2}{*}{ Israel - Mizrahi } & $-.854 * *$ & $-.725 * *$ & $-.587 *$ & -.540 & $-.717 * *$ & $-.652 * *$ \\
\hline & $(.180)$ & $(.184)$ & $(.291)$ & $(.300)$ & $(.188)$ & $(.192)$ \\
\hline \multirow[t]{2}{*}{ Immigrant - Mizrahi } & $-.763 * *$ & $-.665 * *$ & -.444 & -.429 & $-.538^{*}$ & $-.489 *$ \\
\hline & $(.176)$ & $(.180)$ & $(.278)$ & $(.285)$ & $(.185)$ & $(.189)$ \\
\hline \multirow[t]{2}{*}{ Immigrant - Former SU } & $-1.363^{* *}$ & $-1.045 * *$ & $-.645^{*}$ & -.510 & $-.473^{*}$ & -.319 \\
\hline & $(.172)$ & $(.180)$ & $(.266)$ & $(.283)$ & $(.174)$ & $(.183)$ \\
\hline \multirow[t]{2}{*}{ Arab-Muslim } & $-1.789 * *$ & $-1.128 * *$ & $-1.235^{* *}$ & $-.782 *$ & .189 & $.626^{*}$ \\
\hline & $(.203)$ & $(.215)$ & $(.358)$ & $(.379)$ & $(.188)$ & $(.201)$ \\
\hline \multirow[t]{2}{*}{ Arab-Other } & $-1.358 * *$ & $-.987 * *$ & $-1.181 *$ & -.915 & -.008 & .247 \\
\hline & $(.276)$ & $(.283)$ & $(.515)$ & $(.521)$ & $(.252)$ & $(.259)$ \\
\hline \multirow[t]{2}{*}{ Female } & $-.343 * *$ &.$- .348 * *$ & $-.301 *$ & $-.284 *$ & -.026 & -.017 \\
\hline & $(.077)$ & $(.079)$ & $(.138)$ & $(.140)$ & $(.076)$ & $(.078)$ \\
\hline Age & & & & & & \\
\hline
\end{tabular}




\begin{tabular}{|c|c|c|c|c|c|c|}
\hline $30-39$ & .252 & .190 & $.714^{*}$ & $.640 *$ & .113 & .069 \\
\hline & $(.130)$ & $(.132)$ & $(.256)$ & $(.258)$ & $(.125)$ & $(.127)$ \\
\hline \multirow[t]{2}{*}{$40-49$} & $.612 * *$ & $592 * *$ & $.828 *$ & $.765 *$ & $.348 *$ & $.325 *$ \\
\hline & $(.151)$ & $(.155)$ & $(.295)$ & $(.300)$ & $(.146)$ & $(.149)$ \\
\hline \multirow[t]{2}{*}{$50-64$} & $.622 * *$ & $.685^{* *}$ & $.963 * *$ & $.932 *$ & $.450 *$ & $.458 *$ \\
\hline & $(.160)$ & $(.165)$ & $(.301)$ & $(.309)$ & $(.154)$ & $(.159)$ \\
\hline \multirow[t]{2}{*}{$65+$} & $.613 * *$ & $.765 * *$ & $.878 *$ & $.870 *$ & .185 & .222 \\
\hline & $(.189)$ & $(.199)$ & $(.350)$ & $(.362)$ & $(.184)$ & $(.191)$ \\
\hline \multicolumn{7}{|l|}{ Marital Status } \\
\hline \multirow[t]{2}{*}{ Divorce/Separated } & $-.467 * *$ & $-.471 *$ & -.032 & -.097 & $-.329 *$ & $-.341 *$ \\
\hline & $(.136)$ & $(.138)$ & $(.221)$ & $(.223)$ & $(.134)$ & $(.135)$ \\
\hline \multirow{2}{*}{ Widowed } & $-.396 *$ & $-.313 *$ & .147 & .183 & $-.349 *$ & $-.319 *$ \\
\hline & $(.154)$ & $(.158)$ & $(.238)$ & $(.240)$ & $(.153)$ & $(.155)$ \\
\hline \multirow{2}{*}{ Single } & -.068 & -.067 & .055 & .028 & $-.243 *$ & -.222 \\
\hline & $(.126)$ & $(.127)$ & $(.237)$ & $(.239)$ & $(.124)$ & $(.125)$ \\
\hline \multicolumn{7}{|l|}{$\begin{array}{l}\text { Salary (Omitted: Irrelevant; Unemployed/Not } \\
\text { in Labor Force) }\end{array}$} \\
\hline \multirow[t]{2}{*}{ INS 0-4000 } & -.023 & -.046 & -.319 & -.338 & -.075 & -.105 \\
\hline & $(.121)$ & $(.122)$ & $(.234)$ & $(.236)$ & $(.116)$ & $(.118)$ \\
\hline \multirow[t]{2}{*}{ INS 4,001-7000 } & .010 & -.092 & .135 & .049 & .150 & .046 \\
\hline & $(.121)$ & $(.122)$ & $(.218)$ & $(.221)$ & $(.117)$ & $(.119)$ \\
\hline \multirow{2}{*}{ INS 7,001-More than 21,000 } & $.992 * *$ & $.816 * *$ & .508 & .400 & $.833 * *$ & $.701 * *$ \\
\hline & $(.156)$ & $(.159)$ & $(.266)$ & $(.270)$ & $(.158)$ & $(.160)$ \\
\hline \multirow[t]{2}{*}{ Self-employed/Employs Others } & $.480 * *$ & $.435 *$ & .467 & .425 & $.454^{*}$ & $.415^{*}$ \\
\hline & $(.170)$ & $(.171)$ & $(.278)$ & $(.278)$ & $(.173)$ & $(.174)$ \\
\hline \multirow[t]{2}{*}{ Homeowner } & $.308^{* *}$ & $.233 *$ & .197 & .180 & $.262 * *$ & $.230 *$ \\
\hline & $(.083)$ & $(.085)$ & $(.148)$ & $(.151)$ & $(.082)$ & $(.083)$ \\
\hline \multicolumn{7}{|l|}{$\begin{array}{l}\text { Education (Omitted: Less than HS } \\
\text { Matriculation) }\end{array}$} \\
\hline \multirow[t]{2}{*}{ BA or higher } & $1.555^{*} *$ & $1.489 * *$ & $.571 *$ & $.562 *$ & $.976 * *$ & $.942 * *$ \\
\hline & $(.122)$ & $(.124)$ & $(.208)$ & $(.210)$ & $(.123)$ & $(.125)$ \\
\hline \multirow[t]{2}{*}{ Matriculation - LT BA } & $.763 * *$ & $.687 * *$ & .257 & .234 & $.516^{* *}$ & $.461 * *$ \\
\hline & $(.086)$ & $(.088)$ & $(.156)$ & $(.159)$ & $(.085)$ & $(.087)$ \\
\hline \multicolumn{7}{|l|}{ Language Proficiency } \\
\hline Very Good & & $1.276 * *$ & & .522 & & $.426^{*}$ \\
\hline
\end{tabular}




\begin{tabular}{|c|c|c|c|c|c|c|}
\hline & & $(.176)$ & & $(.279)$ & & $(.146)$ \\
\hline Good-Fair & & $.997 * *$ & & .338 & & $.327 *$ \\
\hline & & $(.161)$ & & $(.247)$ & & $(.127)$ \\
\hline \multicolumn{7}{|l|}{ Religiosity (Omitted: Not Religious/Secular) } \\
\hline \multirow[t]{2}{*}{ Very Religious } & & $-.787 * *$ & & $-.778 * *$ & & $-.585 * *$ \\
\hline & & $(.113)$ & & $(.221)$ & & $(.112)$ \\
\hline \multirow[t]{2}{*}{ Religious } & & $-.378 * *$ & & -.208 & & -.078 \\
\hline & & $(.092)$ & & $(.154)$ & & $(.092)$ \\
\hline \multicolumn{7}{|l|}{ Meet Friends (Omitted: No) } \\
\hline \multirow[t]{2}{*}{ Less than Twice a Month } & & $.313^{*}$ & & .011 & & $.296 *$ \\
\hline & & $(.144)$ & & $(.246)$ & & $(.136)$ \\
\hline \multirow[t]{2}{*}{ 1-2 a Month } & & $.403 *$ & & .108 & & $.574 * *$ \\
\hline & & $(.121)$ & & $(.202)$ & & $(.114)$ \\
\hline \multirow[t]{2}{*}{ Daily } & & $.271 *$ & & .138 & & $417 * *$ \\
\hline & & $(.123)$ & & $(.204)$ & & $(.117)$ \\
\hline \multirow[t]{2}{*}{ Someone to Count on } & & $.408 * *$ & & -.170 & & .168 \\
\hline & & $(.116)$ & & $(.180)$ & & $(.106)$ \\
\hline \multirow[t]{2}{*}{ Intercept } & -.160 & -.130 & -1.395 & -1.599 & .088 & .244 \\
\hline & $(.29)$ & $(.355)$ & $(.539)$ & $(.627)$ & $(.259)$ & $(.331)$ \\
\hline
\end{tabular}

\section{Significant at: *.05 $* * .01 \quad * * * .001$}

All models include dummy variables for District and "Unknown" salary. 